\title{
Aegean in Motion: The Reasons, Consequences, and Tragedies of Four Distinct Phases of Migration in the Aegean Sea
}

\author{
Şahizer Samuk* \\ Hazal Papuççular**
}

\begin{abstract}
This study deals with the concept of Aegean in Motion and this concept's conflict with migration policymaking in Turkey. We argue that the region has always been a route for immigration and emigration with distinct causes and consequences. Our aim is to focus on four different and massive phases of this motion. First, we look at the period that started in the nineteenth century and ended with the Turkish-Greek population exchange. This wave was closely associated with war, state building, and the aims of ethnic homogenization within newly-formed borders. The second phase of this migration started with the rising fascist policies of Italy in the Dodecanese in the second half of the 1930s and reached its peak during the Second World War. This period, again related to political crisis and war, indicates fragmented policies by the host state, Turkey, towards different nationalities: Turks, Greeks, and Axis soldiers. The third phase of movement was in the post-1980 period, when Turkey became an immigration and so-called "a transit country". It was discovered later that the migrant and refugee journeys were fragmented and refugees were stranded in the region. The post-2000 period faced many dilemmas: major numbers of crossings from Turkey to Greek shores, thousands of deaths in one year, the readmission deal between the EU and Turkey and the strengthening of border controls via Frontex and EU externalization of migration policy. These four phases are examined via archival work and desk-based research/literature review of articles with a historical perspective, and for each phase a model of immigration policy and state response to/ facilitation of these mobilities will be elaborated.
\end{abstract}

Keywords: Aegean Sea, illegalization, instrumentalization of migration, history of migration, Turkish immigration politics

\section{Özet}

Ege'nin Devinimi: Ege Denizi'ndeki Dört Farklı Göç Evresinin Felaketleri, Sebepleri ve Sonuçları

Bu çalışma, Ege'nin devinimi konseptinin Türkiye'de oluşturulan göç politikalarıyla olan çelişkilerini incelemektedir. Ege'nin farklı sebep ve sonuçlarla da olsa her zaman bir göç rotası olduğunu belirtmektedir. Makalenin amacı dört farklı dönemdeki göçün aşamalarına dikkat çekmektir. Çalışmada öncelikle, 19. yüzyıl ile başlayan ve Türk-Yunan Nüfus Mübadelesi ile sona eren döneme bakılacaktır. Bu göç akımı daha çok, savaş, devlet kurma ve yeni yeni oluşturulan sınırlarla birlikte etnik homojenleştirme politikası ile yakından ilintilidir. İkinci dönemdeki göç ise 1930'ların sonunda İtalya'daki faşist politikaların yükselişiyle ortaya çıkıp II. Dünya Savaşı sırasında zirveye ulaşmıştır. Bu dönem, yine siyasi krizler ve savaş ile ilintili olarak Türkiye'nin göç alan devlet konumuna geldiğini göstermekte ve farklı gruplara uyguladığı çeşitli politikalarını sergilemektedir: Türkler, Yunanlar, ve Mihver askerleri. Üçüncü dönemdeki hareket ise 1980 sonrasına denk gelmektedir. Bu dönem Türkiye'nin hem göç alan hem de transit ülke olarak anıldığı bir zaman dilimdir. Yapılan araştırmalara göre, mültecilerin yolculuğu transit ve kısa zamanda değil, bölük pörçük bir yolculuktur ve birçok mülteci Türkiye'de uzun süre geçirmek zorunda kalmıştır. 2000 sonrası dönemde ise göç politikaları birçok çıkmazla karşı

* University of Luxembourg, Department of Geography and Spatial Planning

** İstanbul Kültür University, Department of International Relations 
karşıya kalmıştır: Türkiye'den Yunanistan'a geçen yüksek sayıdaki göçmenler, mülteciler, bir sene içinde gerçekleşen binlerce ölüm, Avrupa Birliği (AB) ve Türkiye arasında imzalanan Geri Kabul Anlaşması, Türkiye'nin Yunanistan ile olan sınırlarının Frontex ile güçlendirilmesi ve AB'nin göçü dışsallaştırma politikası. Bu dört dönem arşiv çalışmaları ve literatür taramasında akademik makalelerin tarihsel bir şekilde kategorize edilmesi ile incelenmiştir. Her dönem için bir göç politikası modeli ve devletin göçe verdiği tepki incelenmektedir.

Anahtar sözcükler: Ege Denizi, yasadışılaştırma, göçün araçsallaştırılması, göç tarihi, Türkiye'nin göç politikaları

\section{Introduction}

This paper will examine the transformation of immigration and immigration policies of Turkey, dividing it into relevant periods since the late Ottoman Empire. Many studies have been carried out on Turkish immigration policies, but none of them have drawn attention to the fact that this transformation can also be examined by change in both policy discourse and concepts that have become themselves politicized for many reasons. Our research calls attention to the fact that movements from Middle East and other parts of the world to Turkey, and from Turkey to Europe, often necessitated new immigration policies. Throughout the years, governments, migrant flows, international actors, the story of immigration and immigration policies have all changed in Turkey. How and why these policies are modified will be one of the main explorative aspects of this paper. The second aim of the paper is to demonstrate that, although policymaking reveals a long-term vision from time to time, it still neglects the geographical and historical perspectives and Aegean in motion.

This paper investigates Turkish immigration policies from a theoretical perspective that tries to reinterpret the forces that pressured policymakers, such as international actors, national actors, and immigrants. Though immigrants were surely present before these policies were devised, they were the first players of the game. They might have had a limited voice in the last immigration and integration policies; however, they have also turned Turkey into "a land of diverse migrations." Immigrants made it possible to use the concept of "superdiversity" 2 in the Turkish case. The immigrants are the ones for whom policies are made and unmade. Indirectly, immigrants have been influential in contributing to the content of policy discourse and to the formation of diverse integration measures.

Regarding borders and how the migration crisis was framed, Cantat deconstructed "the discourse according to which Europe is experiencing a migrant crisis by relocating recent mobilities in a larger history of confrontation between sovereign power and movement." 3 Inspired by her work, we argue that the role

1 Ahmet İçduygu and Kemal Kirişci, “Introduction: Turkey's International Migration in Transition," in Land of Diverse Migrations: Challenges of Emigration and Immigration in Turkey, ed. Ahmet İçduygu and Kemal Kirişci (İstanbul: İstanbul Bilgi University Press, 2009), 1-35.

2 For more information, see Steven Vertovec, "Super-diversity and Its Implications," Ethnic and Racial Studies 30, no. 6 (2007): 1024-1054. Definition of diversity according to Vertovec (p. 1025) is: "a multiplication of significant variables that affect where, how and with whom people live. In the last decade the proliferation and mutually conditioning effects of a range of new and changing migration variables shows that it is not enough to see 'diversity' only in terms of ethnicity, as is regularly the case both in social science and the wider public sphere."

3 Celine Cantat, "Rethinking Mobilities: Solidarity and Migrant Struggles Beyond Narratives of Crisis," Intersections: East European Journal of Society and Politics 2, no. 4 (2016): 11-32. 
the EU and Turkey played by accepting the Readmission Agreement has contributed more to the strengthening of the outer borders of the EU, setting aside the existence of border crossers' agency. In fact, those who travel within the heart of the EU as daily border crossers are called "frontaliers", ${ }^{4}$ but those who try to cross the Aegean Sea are called "illegal" or "irregular". Cantat, in her work, found out that "the discourse of Mediterranean solidarity was actively relayed, appropriated and mobilised by migrants and activists". ${ }^{5}$ This view is also a crucial starting point for our paper.

This article was inspired by the question of how the Aegean Sea became a space of separation, a geographic entity in which the literal borders have never been clear, but were rather created artificially, and how the passage from south to north and east to west have been heavily impeded upon by the relevant receiving nation-states and the EU.

In the first section of this paper, immigration in the Aegean will be historicized from the late Ottoman period to the end of the Second World War. First, it will be shown that the movements of the people in the region during the late Ottoman Era turned into a tool for state-building. Afterwards, a second phase, which was highly influenced by the political and military situation in the Aegean Sea, will be analyzed. The immigration process in the interwar years were closely related to the political authoritarianism, and as a result, regime opponents were forced to flee. This process changed its shape and scope, reaching its peak during the Second World War.

In the second part of the paper, we will look at the post-1980 period, when Turkey started to be called an immigration country as well as a transit one. To this day, Turkey has not lifted geographical limitations to the Convention Relating to the Status of Refugees, also known as the 1951 Refugee Convention. However, the country has also not implemented this limitation fully throughout the years. In the 1980s the border with Middle Eastern neighbors was less porous compared to the period starting with 2013, in receiving refugees (although there is conflicting research evidence). ${ }^{6}$ The Aegean border and the territorial borders between Turkey and Greece and Turkey and Bulgaria were used by immigrants as gateways to reach Europe in the 1980s, for they did not perceive their future in Turkey as there were not proper de jure integration policies for refugees. Following these thoughts, we will analyze the post-2000 policies, as this period is characterized by a more open-minded policymaking process and is when the Directorate General of Migration Management (DGMM) was established. Moreover, the first Law on Foreigners and International Protection was adopted on the 4th of April 2013. However, the recent setbacks with the Readmission deal between EU and Turkey in March 2016 demonstrates that the policymaking is still entrapped within path dependency and preeminence of border enforcement, whilst migrants' agency is neglected when devising immigration policies. $^{7}$

4 A term used for Belgian, French and German employees who come to Luxembourg to work and leave in the evening on a daily basis.

5 Cantat, "Rethinking Mobilities", 28.

6 Burcu Toğral Koca, “Deconstructing Turkey's 'Open Door' Policy Towards Refugees from Syria," Migration Letters 12, no. 3 (2015): 209-225.

7 Nick Squires, “A Year on from EU-Turkey Deal, Refugees and Migrants in Limbo Commit Suicide and Suffer from Trauma," accessed March 14, 2017, https://www.telegraph.co.uk/ news/2017/03/14/year-eu-turkey-deal-refugees-migrants-limbo-commit-suicide-suffer/. 


\section{Aegean in Motion: Migration as a Nation-Building Process}

In the late Ottoman Empire, migration, which was mostly related to the war and loss of territories, became a process in the way of transformation from a multiethnic empire to a relatively homogenous nation-state. Politics of population, as İçduygu, Toktaş and Soner highlight, became a tool of the nation-building process, which necessitated the elimination of "other" through different means, including (forced) migration. ${ }^{8}$ One of the most important reflections of this understanding, particularly with regard to the Aegean, was the period starting with the Balkan Wars and ending with the Turco-Greek population exchange, through which people were forced to leave their homelands.

From the perspective of politics of population, or nation-state building, the loss of territories mostly inhabited by the non-Muslim communities of the empire, as well as the migration of the Muslim communities from these areas during the course of the nineteenth century, constituted the beginning of a process of transformation for the Ottoman Empire. ${ }^{9}$ Similar to the wars with the Russians during the nineteenth century, the Balkan Wars became another important step in the nation-state building process of Turkey; this was not solely in terms of the changing population dynamics concerning incoming Muslims, but of the trauma that the war caused in the minds of the ruling elite, who would exchange its already-reluctant Ottomanist ideology for Turkism. It was with this ideology that the Committee of Union and Progress would implement strategies to "Turkify" Anatolia, including the deportation and mass violence imposed upon the Armenians during the First World War. ${ }^{10}$

The Balkan Wars were important also for migration in the Aegean. First, during both the Italo-Turkish War and the Balkan Wars, the Ottoman Empire had lost the Aegean Islands just facing the Western Anatolian shores, leading to a movement of the people in the region. Second, the Committee of Union and Progress specifically focused on the settlement of the Turkish refugees coming from the Balkans to the Ottoman Empire in Western Anatolia and Thrace. ${ }^{11}$ This led to an ethnic friction between the newcomers and the Anatolian Greeks; the latter started to flee from Anatolia mostly to the Aegean Islands and Thrace. ${ }^{12}$

As Yıldırım shows, these were also the times that Istanbul and Athens discussed a voluntary exchange treaty, the implementation of which remained controversial according to the existing sources. ${ }^{13}$ However, it has been roughly estimated that 200,000 Greeks left Western Anatolia with the outbreak of the First World War. ${ }^{14}$ This period shows that the first ideas of the population ex-

8 Ahmet İçduygu, Şule Toktas, and B. Ali Soner, "The Politics of Population in a Nation-building Process: Emigration of Non-Muslims from Turkey," Ethnic and Racial Studies 31, no. 2 (2008): 358-360.

9 Kemal Karpat, Ottoman Population, 1830-1914: Demographic and Social Characteristics (Madison, Wisconsin: University of Wisconsin Press, 1985), 65-75.

10 For more information about the orientation of the ruling elite towards the Anatolia after the Balkan Wars, see Fuat Dündar, İttihat ve Terakki'nin Müslümanları İskân Politikası (1913-1918) (İstanbul: İletişim Yayınları, 2002), 36-40.

11 Dündar, Ittihat ve Terakki'nin Müslümanları Iskân Politikası, 168.

12 Ayhan Aktar, "Homogenising the Nation, Turkifying the Economy," in Crossing the Aegean: An Appraisal of the 1923 Compulsory Population Exchange Between Greece and Turkey, ed. Renée Hirschon (New York and Oxford: Berghahn, 2003), 82-83.

13 Onur Yıldırım, Diplomacy and Displacement: Reconsidering the Turco-Greek Exchange of Populations, 1922-1934 (New York: Routledge, 2006), 5.

14 Aktar, "Homogenising the Nation," 83. 
change in the region based on ethnic lines had been discussed much earlier than the Turco-Greek War. The states in the Balkans had aimed to build their nation-states by utilizing the movement of the people that would homogenize both the society and economy.

The motion of people in the region continued throughout the Great War. ${ }^{15}$ Therefore, Hirschon rightly states that, although the Turco-Greek population exchange (1923) was regarded as the culmination of this "unmixing" of people with its compulsory nature, this process of homogenization through migration had already been started. ${ }^{16}$ The Greek landing in Western Anatolia in 1919, which started a war between the Greek army and the Kemalist forces, became another turning point for migration practices. This is especially true for the latter phase of this war, in which the Kemalists gained victories over the Greeks and more than a million people fled to Greece. ${ }^{17}$

After the end of the Turco-Greek War, the parties under the auspices of the Entente started to discuss a compulsory exchange of populations, as living together after years of war and violence was regarded as almost impossible. On 30 January 1923, the ruling elite of the two powers reached an agreement for a population exchange to further consolidate their nation-states, which should have been as homogenous as possible. ${ }^{18}$ Although the majority of the Western Anatolian Greeks had already migrated under the conditions of war as stated above, approximately 180,000 people were transferred to Greece after the population exchange. ${ }^{19}$ Likewise, roughly 350,000 refugees came from Thrace and the Aegean Islands to Turkey as a result of the implementation of this treaty. ${ }^{20} \mathrm{In}$ conclusion, after this ten-year process, although both states were far from being absolutely homogenous, the motion in the Aegean had brought them closer to their ideals.

\section{The Second Phase of the Refugee Crisis: The Aegean in the Second World War}

Similar to the First World War, and specifically the Turkish War of Independence, a humanitarian crisis was experienced on the shores of the Aegean during the Second World War. The refugees fleeing from the war, particularly from the Aegean Islands and mainland Greece, constituted a multifaceted issue for both Turkey and the Allies in this period. However, it should be noted that the migration between the coasts did not start with the outbreak of the war: between the Turkish-Greek population exchange and the Second World War, people continued to move in the Aegean Sea. Even if the migration of the interwar period never reached a level of a crisis, it is important to know that people were also moving in the region during this time frame.

One of the significant reasons for the movement of the people in the Aegean in the interwar period was political in nature. For instance, according to the

15 Karpat, Ottoman Population.

16 Renée Hirschon, "Unmixing Peoples in the Aegean Region," in Crossing the Aegean: An Appraisal of the 1923 Compulsory Population Exchange Between Greece and Turkey, ed. Renée Hirschon (New York and Oxford: Berghahn, 2003), 4.

17 Hirschon, "Unmixing Peoples in the Aegean Region," 6.

18 Yıldırım, Diplomacy and Displacement, 8.

19 Renée Hirschon, "The Consequences of the Lausanne Convention: An Overview," in Crossing the Aegean: An Appraisal of the 1923 Compulsory Population Exchange Between Greece and Turkey, ed. Renée Hirschon (New York and Oxford: Berghahn, 2003), 13.

20 Hirschon, "The Consequences of the Lausanne Convention," 13. 
documents found in the Historical Archives of the Italian Ministry of Foreign Affairs, people who were the opponents of the Kemalist regime in the 1920s, including the famous 150liks, were expelled from Turkey to the Italian Dodecanese. It is seen from the same documents that the Turkish government was uncomfortable about the Turks living on Rhodes and Kos, and even tried to make an agreement with the Italians during the late 1920s to solve the matter. ${ }^{21}$ Likewise, in the northern part of the archipelago, the Turkish government tried to control anti-Kemalist Turkish refugees living in the Greek mainland and islands through its consulates. ${ }^{22}$

In the second half of the 1930s, another wave of politically-driven migration took place between the Italian Dodecanese and Anatolian coasts due to the total militarization of the islands, especially during Italy's Abyssinian venture (19351939), and due to strict cultural policies, or harsh Italianization starting in 1936. Using this route, not only did the Muslims living on the islands try to escape from the Dodecanese, but also the Greeks and Italians. Turkey permitted the Muslims who fled from the islands to settle in Anatolia, thus paving the way for Italian accusations against the Turks, who were encouraging this migration to make refugees the supporter of Ankara, according to Rome. ${ }^{23}$ Greeks also ran away from the islands, although their numbers were not obvious. In such cases, Turkey tried to send these people who were oppressed by fascism not to the Dodecanese but to Greece. ${ }^{24}$ Yet, Greece sometimes did not accept these refugees. In such cases, it is interesting to see that Turkish officials even discussed smuggling the Greek refugees to the Greek islands ${ }^{25}$ rather than to the Dodecanese, where they would likely be executed upon return. It can thus be concluded that these Greek refugees constituted a problem for Turkish diplomacy. When it is also considered that Italians soldiers fled to Turkey in small boats to escape the tough conditions of military service, it is understood that refugees had already become a diplomatic problem between the states on the eve of the Second World War. However, with the war's emergence this diplomatic issue would become an intense humanitarian crisis.

In 1940, as Italy entered the war and Axis forces began to invade Greece, people started to migrate from Greece (both the mainland and its islands) and the Italian Dodecanese. One of the most important reasons for migration was the famine that heavily impacted both Greece and the Dodecanese. After the outbreak of the war, the Allies (particularly Britain) insisted on a blockade that would be strictly implemented in the Aegean Sea. Turkey thus controlled and restricted commercial activities in the Aegean Sea, not only because of British insistence, but because of the necessities of its own economy. ${ }^{26}$ Since the economy of the Aegean islands depended mostly on trade between coasts, islanders began to deal with acute famine conditions, which would lead them to migrate

21 Archivio Storico del Ministero degli Affari Esteri (ASMAE), Busta Dodecanneso 1, "Trattato di Buon Vicinato fra Turchia e Possedimento," (Good Neighborhood Treaty between Turkey and the Possession), 26 June 1931.

22 Kevin Featherstone, et al., The Last Ottomans: The Muslim Minority of Greece, 1940-1949 (New York: Palgrave Macmillan, 2011), 43-44.

23 ASMAE, Busta Dodecanneso 13, "Voci Tendenziose sulle Isole dell'Egeo," (Biased Voices on the Aegean Islands), 17 September 1937.

24 TC Başbakanlık Cumhuriyet Arşivi, 30..10.0.0/116.84..2, 30 May 1936.

25 TC Başbakanlık Cumhuriyet Arşivi, 30..10.0.0/116.84..2, 30 May 1936

26 The National Archives, FO 371/29932, “Telegram from Ministry of Economic Warfare to Foreign Office," 11 January 1941. 
to Anatolia. In this respect, from 1940 onward civilians and soldiers alike had fled to the coasts of Turkey. ${ }^{27}$

It should be noted that statistical data about these refugees are both incomplete and complex. Most of the data provide the numbers of refugees coming from the Dodecanese and Northeastern Aegean Islands together. Despite this, a general picture could be drawn based on the political developments in the region. The Second World War regarding the nature of the dense Aegean migration towards Turkey can be divided into two subperiods: the phase between 1941 and 1943, and that during and after 1943. It may be well assumed that any statistical data regarding the first sub-period was more related to the northern Aegean part, due to the war and occupation in Greece at that period; a similar understanding can be applied to the Italian Dodecanese for the period during and after 1943 owing to the Italian withdrawal, British campaign, and German occupation at that time. It should be noted that this statement is a rough generalization to be considered for its emphasis on the preponderance of refugees' originating points, rather than for its exact accuracy.

Despite this complicated situation, there are several statistics provided by various sources that are crucial to understanding the situation during the war. Iskan Umum Müdürlüğ̈̈ shows that the number of Greek refugees coming both from the Northern Aegean islands under Nazi occupation and from the Italian Dodecanese between 1941 and 1943 was 22,909. ${ }^{28}$ Likewise, according to the Danacioğlu's work, 19,735 refugees were added to the picture between September 1943 and November 1944, during which the unsuccessful campaign of the British took place. ${ }^{29}$ The majority of these numbers in late 1943 belonged to the Dodecanese, from which not only the civilians, but also the British and Italian soldiers fled to Turkey. When the approximate population of the Dodecanese Islands - 120,000 civilians based on the 1936 census - is kept in mind, the significance of the migration process can be fully appreciated. According to the Greek reports, which show that an additional 20,000 people fled from the Dodecanese in the first two months of $1944,{ }^{30}$ exodus continued mostly because of the deteriorating famine after the German takeover of the region.

Turkey's reactions to the refugees were diverse. Ankara was uncomfortable with the refugees because of financial reasons; therefore, Turkish officials frequently emphasized that the government should have taken the necessary measures to prevent people from migrating, as refugees were damaging the state budget that had already been negatively affected by the war. ${ }^{31}$ The first measures had in fact been ineffective; this would later be seen in Ankara's decision to stop accepting refugees in $1942,{ }^{32}$ after which people continued to arrive on the Turkish coasts. Turkey then stiffened its position on migration, especially after the second wave in 1943. The majority of attempted migrants were not

27 The National Archives, FO 195/2468, “Telegram from British Consulate General (Symirna) to Sir H. Knatchbull-Hugessen (Angora)," 13 November 1940.

28 TC Başbakanlık Cumhuriyet Arşivi, 30..10.0.0/124.882..4, 8 March 1943.

29 Esra Danacıŏlu-Tamur, “Ege'de Büyük Kaçış: II. Dünya Savaşı'nda Adalardan Türkiye'ye Mülteci Akını," Toplumsal Tarih 25, no. 146 (Şubat 2006): 55.

30 Lena Divani, and Photini Konstantopoulou, eds., The Dodecanese: The Long Road to Union with Greece: Diplomatic Documents from the Historical Archives of the Ministry of Foreign Affairs (Athens: Kastaniotis Editions, 1997), 154-155.

31 TC Başbakanlık Cumhuriyet Arşivi, 30..10.0.0/124.882..4, 8 March 1943.

32 Ulvi Keser, Yunanistan'ın Büyük Açlık Dönemi ve Türkiye (İstanbul: IQ Kültür Sanat Yayınları, 2008), 371-372. 
granted authorization to enter Turkey and continued waiting on their boats in the Aegean. ${ }^{33}$ Starting with the beginning of the war, yet mostly after 1943, Ankara implemented several strategies through which refugees were sent to Allied camps in Syria and Cyprus, or to the Prisoner-of-War Camps (POW) as interned soldiers. ${ }^{34}$ It should be noted that the Allies were not fond of the Turkish position towards the refugees either politically or financially, frequently reminding the administration of their uneasiness even after the war's conclusion. ${ }^{35}$

Two exceptions to the rigid Turkish position towards refugees were based on ethnic considerations. First, Ankara accepted its kin group, in other words the Turkish minority, and allowed them to settle in Anatolia rather than sending the group to the refugee camps in or outside of the country. However, even in these cases, Ankara restricted the group to settling in a predetermined area and did not permit them to leave these regions, as the country intended to send them back after the war. ${ }^{36}$ Indeed, after 1945, Turkey would rush to return at minimum the Dodecanesians, due to their concerns over the region's future sovereignty, which could possibly be determined by a plebiscite. ${ }^{37}$ The second group that Turkish authorities allowed to migrate, and even made an effort to enable their migration, was the Jewish community of the Dodecanese. Selahattin Ülkümen, who prepared Turkish passports for the Jews and saved them from going to concentration camps, ${ }^{38}$ would be declared Righteous among the $\mathrm{Na}$ tions by the state of Israel later on, being the first Muslim with this title. ${ }^{39}$

The second phase of migration in the Aegean would be completed in 1947, in which the majority of migrants returned to their homelands, yet with bitter memories of violence, famine, POW camps and death camps. A new phase would start with different dynamics in the 1980s.

\section{Illegalization of Aegean Sea: Turkey as an Immigration Country, as a Transit Country, or Both?}

Refugee flows to Turkey were seen as results of the occupation of Afghanistan by Russia in the 1970s, regime change in Iran in 1979 and oppressions of Kurdish population during the Saddam regime. After the collapse of the Union of Soviet Socialist Republics, Eastern European and Russian migrants also started to arrive in Turkey. On the other hand, there were some refugees from Turkey emigrating to EU countries: "between 1983 and 2000, 490 thousand Turkish citizens applied for asylum in various European countries". ${ }^{40}$ Respecting these changes of incoming migration, Turkey had to deal with a refugee flow from diverse countries; the 1994 Regulation on Asylum was thus enacted. Accord-

33 ASMAE, Busta Dodecanneso 16, "Notizie da Rodi," (Information from Rhodes), 13 January 1945, 25 January 1945.

34 Keser, Yunanistan'ın Büyük Açlık Dönemi, 371-72.

35 The National Archives, FO 195/2487, Telegram from Sir M. Peterson to Foreign Office, 5 April 1945.

36 TC Başbakanlık Cumhuriyet Arşivi, 30..10.0.0/124.882..12, 2 May 1945.

37 ASMAE, Busta Dodecanneso 16, "Notizie dal Dodecanneso," (Information from the Dodecanese), 25 July 1945.

38 For a more detailed narrative of deportation, see "Holocaust," Rhodes Jewish Museum, accessed January 13, 2013, http://www.rhodesjewishmuseum.org/history/holocaust.

39 Righteous Among the Nations is an honour that Israel gives to those who risked their lives in order to save Jews.

40 Kemal Kirişci, “Turkey: A Country of Transition from Emigration to Immigration," Mediterranean Politics 12, no. 1 (2007): 91-97. 
ing to the Migration Policy Group (MIGPOL), this law "cemented the system of differential treatment for European and non-European refugees"41 ${ }^{\prime \prime 2}$ rather than abolishing the geographical limitation.

The immigration patterns of the refugees coming from Middle Eastern countries at this time was considered as "illegal migration", though the term changed to "irregular migration" or "undocumented migration" as academics drew attention to the fact that it is unethical and unacceptable to use the term "illegal". In other words, people cannot be illegal, though crossings may be. However, as a result of globalization processes, the fight against illegal migration has become a definitive part of global migration discourse. Simultaneously, Turkey was becoming a land for asylum-seekers, refugees, regular migrants and irregular migrants. ${ }^{42}$ The policy discourse that ran somehow parallel to that against illegal migration concerned "transit migration", a term whose zenith was reached during the early 2000s. Transit migration was a politically-loaded concept ${ }^{43}$ as it focused on crossing borders either via sea or land from Turkey to the EU. This term underlined the depiction of Turkey as a bridge from the Middle East to Europe. Moreover, it also meant that borders between Greece and Turkey were not controlled efficiently, which resulted in unwanted transit.

There has been an extensive amount of research published concerning the politics of irregular migration..$^{44}$ Kirişci underlined how Turkey became a buffer zone while the EU earned its image as a fortress ${ }^{45}$, for Turkey's interests in keeping the immigrants away from EU's external borders were adversely affected by this process of EU-ization. Turkey was seen by one of the structural actors, such as the EU, as a bridge between Asian and Middle Eastern countries, which made it possible to think of immigration into Europe from Turkey as illegal. From this angle, the promotion of securitization of immigration policies in Turkey was justified. This justification can even be strengthened by the fact that many European policy experts and policymakers who commented on Turkish prospects for EU membership have accentuated the risk of sharing borders with Middle Eastern countries. ${ }^{46}$

Most of the literature post-1980s dealt with how Turkey has become an immigration country as well as a transit one ${ }^{47}$ One of the first immigration patterns concerned the shuttle traders, who had a circular pattern of migration

41 "Migration \& Mobility," MigPolGroup, accessed September 22, 2017, http://www.migpolgroup.com/migration-mobility/.

42 All these categories have been constructed in a better way either for academic reasons or for managing migration, the discussion regarding how useful these categories are beyond the scope of this paper.

43 Franck Düvell, "Transit Migration: A Blurred and Politicised Concept," Population, Space and Place 18, no. 4 (2012): 415-427.

44 For more information see Kemal Kirişci, Managing Irregular Migration in Turkey: A Politicalbureaucratic Perspective, CARIM-AS 2008/61 (Robert Schuman Centre for Advance Studies, San Domenico di Fiesole (FI): European University Institute, 2008); Ahmet Iç̧duygu, The Irregular Migration Corridor Between the EU and Turkey: Is It Possible to Block It with a Readmission Agreement?, Research Report Case Study EU-US Immigration Systems 2011/14 (Robert Schuman Centre for Advanced Studies, San Domenico di Fiesole (FI): European University Institute, 2011).

45 Eleonore Kofman and Rosemary Sales, “Towards Fortress Europe?,” Women's Studies International Forum 15, no. 1, (Pergamon, 1992): 29-39.

46 This kind of discourse also dominated many policymakers' speeches, such as Sarkozy.

47 For detailed information see Ahmet İçduygu and E. Fuat Keyman, “Globalization, Security, and Migration: The Case of Turkey," Global Governance 6 (2000): 383-398; Kirişci, "Turkey: A Country of Transition," 91-97. 
while buying goods in Turkey and selling them Russia. ${ }^{48}$ Significant works concentrated on female migrants and the feminization of migration into Turkey during the 2000s, which dealt with how women were involved in domestic work, entertainment and the sex industry ${ }^{49}$ while many foreign women were trafficked in Turkey. Besides the feminization of migration in Turkey, academic research of this period also focused on the geographical limitations to the 1951 Refugee Convention. How Turkish immigration policies were changed and transformed has long been a hot topic. Scholars also wrote on the EU-Turkish relations regarding the readmission policy ${ }^{50}$ and changing priorities of progress reports ${ }^{51}$ (Justice and Home Affairs). Meanwhile, there has been inflation in the number of migrant organizations, and the manner in which these organizations provide assistance to migrants/refugees have been portrayed as problematic. ${ }^{52}$

One of the most important arguments from EU-ization papers was related to "burden shifting" and "burden sharing",53 it was suggested that the EU should take more initiatives in respect to the immigration and refugees. However, this wishful thinking has not translated into reality. Burden sharing has been resolved the other way around: financing Turkey and receiving fewer numbers of refugees. In this case, the Mediterranean Sea has become a place witnessing many tragedies and deaths, especially since $2011^{54}$ in Italy's case. Furthermore, since 2015 the tragedies in the Aegean Sea have reached a peak between Greece and Turkey. ${ }^{55}$

\section{Policy Discourse in Fighting Irregular Migration and Nature of Immigration}

Apart from the above-mentioned articles, other immigration-related research areas and policy discourses heavily focused on the counter-trafficking projects

48 For a detailed work in this regard, see Deniz Yükseker, "Shuttling Goods, Weaving Consumer Tastes: Informal Trade Between Turkey and Russia," International Journal of Urban and Regional Research 31, no. 1 (2007): 60-72.

49 For more details, see Ahmet İçduygu and Şule Toktaş, "How Do Smuggling and Trafficking Operate via Irregular Border Crossings in the Middle East? Evidence from Fieldwork in Turkey," International Migration 40, no. 6 (2002): 25-54. For domestic work of immigrant women in Turkey, see Selmin Kaşka, "The New International Migration and Migrant Women in Turkey: The Case of Moldovan Domestic Workers," MiReKoc Research Project 25, 2006. For trafficking in persons and especially for women, see Önder Karakuş, "A Quantitative Analysis of the Growing Business of Organized Crime: Structural Predictors of Cross-national Distribution of Human Trafficking Markets and Trafficking in Women in Turkey" (PhD diss., Michigan State University, 2008).

50 Karakuş, "A Quantitative Analysis of the Growing Business of Organized Crime".

51 Saime Özçürümez and Nazlı Şenses, "Europeanization and Turkey: Studying Irregular Migration Policy," Journal of Balkan and Near Eastern Studies 13, no. 2 (2011): 233-248.

52 Nurcan Özgur Baklacıŏlu, "Building 'Fortress Turkey': Europeanization of Asylum Policy in Turkey," The Romanian Journal of European Studies 7-8 (2009): 103-119.

53 Ahmet İçuygu "EU-ization Matters: Changes in Immigration and Asylum Practices in Turkey," in The Europeanization of National Policies and Politics of Immigration: Migration, Minorities and Citizenship, ed. Thomas Faist and Andreas Ette (London: Palgrave Macmillan, 2007), 201-222.

54 See "Mediterranean Takes Record as Most Deadly Stretch of Water for Refugees and Migrants in 2011," United Nations High Commissioner for Refugees (UNHCR), accessed October 14, 2017, http://www.unhcr.org/news/briefing/2012/1/4f27e01f9/mediterranean-takesrecord-deadly-stretch-water-refugees-migrants-2011.html.

55 "Missing Families Project," International Organization for Migration, accessed October 14, 2017, https://missingmigrants.iom.int/region/mediterranean. 
and the role of smugglers. In fact, these topics are now recurring after the deaths of immigrants ${ }^{56}$ in the Mediterranean and Aegean Seas. The EU's first reaction to the mass crossings by sea concerned how smugglers collaborated and risked the lives of the immigrants. ${ }^{57}$ Policymakers have not questioned the legitimacy of borders on the sea, nor the literal and metaphorical everyday borders within the cities. In other words, borders, counter-trafficking and counter-smuggling measures, prevention of illegal migration and undocumented people's presence in Europe or in Turkey have always been handled by reinstating, remaking and reinforcing the power of the nation-state. The discourse of these policies aimed to promote safe routes for legal migration and weaken the means via which irregular migration occurred. In fact, securitization of migration and the aim to prevent irregular migration ended in more restrictions on general immigration policies, even concerning those who wish to immigrate to European countries through legal channels.

In the second half of the 1990s and the beginning of the 2000s, policy discourse was mostly focused on prevention of transit migration, while the disruption of migrants' journeys and their being stranded were ignored. ${ }^{58}$ The diverse experiences of migrants and the meaninglessness of borders for refugees were thus neglected. Hence, the focus was mostly on policymaking for migration management.

\section{Institutionalization of Immigration Policy in Turkey: Back and Forth between Securitization and Human Rights of Migrants}

Despite the "open door policy" of Turkey,,$^{59}$ securitization of migration and borders is still a concern. ${ }^{60}$ With the Law on Foreigners and International Protection, the country adopted a rights-based approach for improving immigrants' lives. However, legislation in Turkey from the 1990s to 2000s revealed an ambiguous, inconsistent stance; simultaneously, the demands realized in the name of harmonization with the EU Acquis, replicate the EU policies, which are themselves inconsistent regarding securitization and enhancing the rights of immigrants.

In August 2002, Turkey ratified the UN Conventions against Transnational Organized Crime; its additional protocols aimed to prevent human trafficking. In the same year, the Turkish National Security Council adopted a resolution on combatting irregular migration. Furthermore, many other minor measures that take into consideration either the rights of migrant workers or refugees' protection have been espoused in past years. Some of them can be summarized as such: Law on Work Permits for Aliens, Law No. 4817 of 27 February 2003 - annulled Law No. 2007 of 1932- allowed foreign citizens to work as interpreters, guides, photographers, drivers and waiters, as well as in other jobs that used to be open to Turkish citizens only; according to this law anyone who held a

56 "The world's deadliest sea crossing," Amnesty International UK, accessed September 20, 2017, https://www.amnesty.org.uk/worlds-deadliest-sea-crossing-mediterranean.

57 Liz Alderman, "Smugglers Prey on Migrants Desperate to Find Back Doors to Europe," last modified March 11, 2016, https://www.nytimes.com/2016/03/12/world/europe/europeanunion-migrant-crisis-smuggling.html?mcubz=0\&_r=0.

58 Michael Collyer, "Stranded Migrants and the Fragmented Journey," Journal of Refugee Studies 23, no. 3 (2010): 273-293.

59 M. Murat Erdoğan, Türkiye'deki Suriyeliler: Toplumsal Kabul ve Uyum (İstanbul: İstanbul Bilgi Üniversitesi Yayınları, 2015); Sophia Hoffmann and Sahizer Samuk, "Turkish Immigration Politics and the Syrian Refugee Crisis" Working Paper Research Division Global Issues, no. 01, March 2016.

60 Toğral Koca, “Deconstructing Turkey's Open Door Policy,” 209-225. 
residence permit for six months could apply for a work permit (except students). These are the ambivalent years within which Turkey wanted to provide concessions in the name of recognizing migrants' rights. At the same time, the government did not want to risk security issues that could jeopardize any national interest, while trying not to fall short of requirements of the harmonization with the EU Acquis. For instance, "A Strategy for the Protection of External Borders in Turkey" was adopted in 2003. That same year, the Turkish government also began issuing six-month humanitarian visas to victims of trafficking. The Ministry of Health enacted a decree to extend free medical care to victims of trafficking; all these developments have been part of the curriculum for training law enforcement officers. ${ }^{61}$

While summarizing all recent legal developments is beyond the scope of this paper, we would like to emphasize that one-step forward two-steps back, the Turkish government continued to revise its immigration policies, which fluctuated throughout the 2000s. These changes also included work permit regulations improving the livelihoods of migrant workers. At the same time, a concern over protecting the national labor market manifested itself, with the goal that Turkish nationals would not be replaced by immigrants ("Law on Work Permit for Foreigners", No. 4817). Securitization retained its presence in policy discourse and legislation: in 2010 biometric measures were introduced to the visa procedures; in 2012, the "Law on Residence and Travel of Foreigners" came into force and required tourists to leave Turkey for three months during each six-month period in the country.

One groundbreaking change was the adoption of the "Law on Foreigners and International Protection" in April 2013, as well as the establishment of DGMM. This law has achieved success because Turkey had no proper legislation prior to this date, apart from some regulations and decrees, which implied less implementing and enforcing power (especially to protect the rights of the migrants). As many international migrant organizations (Amnesty International, ASAM, Caritas, IOM, UNHCR etc.) have been one voice, their critical and constructive discourses were seemingly influential elements, as the government seemed to be more open to domestic exigencies and to the transformation of migration laws. Despite all these acts, the "Law on Foreigners and International Protection" (Law No. 6458) was condemned because geographical limitations were not lifted and Europeans would be given subsidiary protection, while non-Europeans would have a conditional refugee status. The refugees would thus not be granted proper refugee status until they are to be resettled in a third country. Despite this limitation, it should not be forgotten that this law is a point of reference in terms of legal guarantees for any immigrant category.

Implementation of immigration policies became more organized between 2009 and 2015, in terms of the availability of diverse policy tools for dealing with migration. A huge rise in the number of NGOs and migrant organizations could be easily observed after 2013, which was in line with the rise of Syrian refugees. Establishment of DGMM has been seen as a great improvement, as DGMM was perceived as a way to devise innovative policies to manage migration. Some side effects of dealing with immigration officially have also appeared since the state capacity (DGMM) was established. ${ }^{62}$

61 One of the authors attended these trainings of law enforcement forces regarding migrants' rights and counter-trafficking measures, during her internship at IOM in 2009-2010.

62 There was a debate on the necessity to receive permission from DGMM about writing a thesis on Syrians. Although this was a flexible policy, autonomy in doing research in the future can be prevented. 
Finally, the EU-Turkey agreement signed on 18th of March 2016 has been righteously criticized from both ethical and legal perspectives. The fact that this deal has strengthened the borders in the Aegean Sea can be interpreted as such: rights violations of migrants, who want to cross the borders, might not be compensated through legal channels. Besides, this agreement did not leave many options for refugees wanting to leave Turkey or to continue their journey. In a way, the dangerous border-crossing possibilities ${ }^{63}$ have become the new norm. The graph below demonstrates fatalities by month from 2014 to 2017.

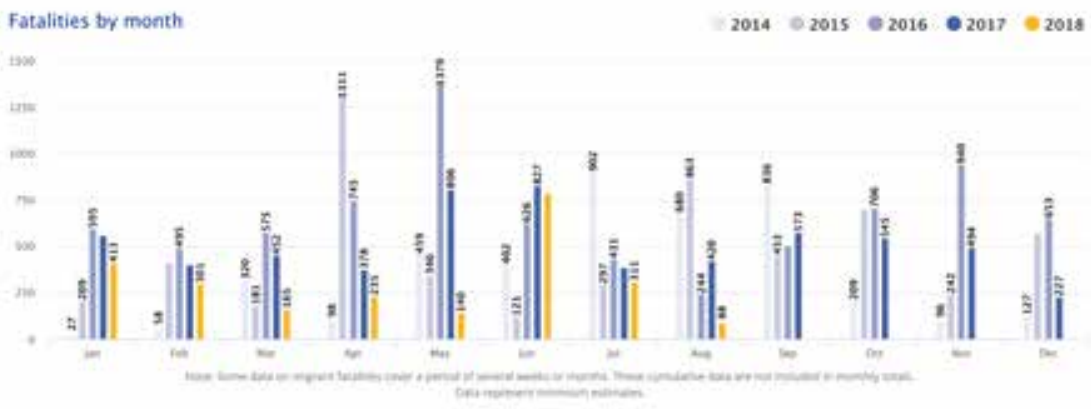

Total number of deaths in the Mediterranean from January 1, 2014 to October 15, 2018 Source: https://missingmigrants.iom.int, accessed August 27, 2018.

\section{EU-Turkey Agreement of 2016 and Instrumentalization of Immigration}

The previous section focused on policy changes from the 1990s to 2012. This section will now focus on the changes between 2012 and 2017, a period within which Turkey became the highest refugee-receiving country in the world. The numbers of Syrian refugees received by Turkey have been by far the largest when compared to Syria's other neighboring countries. ${ }^{64}$ The DGMM website notes:

As of 12/02/2016, 2,778,878 Syrians have been biometrically recorded and Temporary Protection Identity Documents have been issued. Among these foreigners, the number of people in 10 provinces of 26 temporary accommodation centers that are established by the Prime Ministry Disaster and Emergency Management Authority is 256,971, and there are 2,521,907 Syrian foreigners out of these accommodation centers. ${ }^{65}$

Syrians were granted temporary protection status in Turkey, a decision that was criticized fervently by the international community, researchers, and even some migrant organizations. The reason for criticism is that temporary protection is not full protection, and although this legal category provides refugees some social and political securities, the rights granted within this category are

63 "Missing Families Project," International Organization for Migration, accessed October 14, 2017, https://missingmigrants.iom.int/region/mediterranean.

64 "Syria," European Commission, European Civil Protection and Humanitarian Aid Operations, accessed October 14, 2017, http://ec.europa.eu/echo/files/aid/countries/factsheets/ turkey_syrian_crisis_en.pdf.

65 "Statistics," Republic of Turkey, Ministry of Interior Directorate General of Migration Management, accessed December 30, 2016, http://www.goc.gov.tr/icerik3/statistics_1064_4773_10166. 
not as secure as a full refugee status. However, officials justify this decision on the basis that the influx of refugees was too extreme to allow for a thorough identification of case-by-case statuses; comparably, within the EU temporary protection status was given to the mass flows of refugees arriving from Kosovo in the 1990s. ${ }^{66}$

The temporary protection status owners have the right to work officially ${ }^{67}$ in line with the Regulation on Work Permit of Refugees under Temporary Protection, which has been issued in the Official Journal No. 2016/8375, dated January 2016. This political move was praised by the UNHCR in $2016 .{ }^{68}$ However, the volume of Syrian refugees employed in a given workplace shall not surpass $10 \%$ percent of all workers. Moreover, for jobs requiring temporary labor, the conditional quota of having $10 \%$ temporary protection status owners amongst all employees does not apply. This lack of quota for jobs of a temporary nature seems to be the most problematic area as far as we are concerned, knowing how these temporary positions can be highly precarious, especially those in the category of low skilled. ${ }^{69}$

Better late than never, or better having something than nothing, in policy terms, regularizing the situation of refugees, can be thought of as an optimistic approach. Besides all these discussions, the president of Turkey suggested granting citizenship to Syrians. ${ }^{70}$ However, while some Syrians claimed that they would like to have Turkish citizenship, ${ }^{71}$ some young and well-educated ones disagreed with this idea and advocated the idea that citizenship is being used for political purposes. ${ }^{72}$ One such example is that the current president wants to use these great numbers of Syrians to serve his own political power. If this intention truly is part of the hidden political agenda, Syrian refugees are still seen as tools to reach a policy manipulation. Finally, recent developments show that 30,000 Syrian citizens have been granted citizenship. ${ }^{73}$

EU and Turkey can be both glad to have closed a deal that was in both of their interests. In this sense, preventing immigration from Turkey to Europe

66 See "Temporary protection," European Commission, Migration and Home Affairs, accessed October 14, 2017, https://ec.europa.eu/home-affairs/what-we-do/policies/asylum/ temporary-protection_en.

67 Patrick Kingsley, "Fewer than $0.1 \%$ of Syrians in Turkey in Line for Work Permits," last modified April 11, 2016, https://www.theguardian.com/world/2016/apr/11/fewer-than01-of-syrians-in-turkey-in-line-for-work-permits.

68 "UNHCR Praises Turkey's Work Permits for Syrian Refugees", Orient Net, accessed September 30, 2017, http://orient-news.net/en/news_show/100179/0/UNHCR-praises-Turkeyswork-permits-for-Syrian-refugees.

69 See Kerry Preibisch, "Migrant Workers and Changing Work-place Regimes in Contemporary Agricultural Production in Canada," International Journal of Sociology of Agriculture $\mathcal{E}$ Food 19, no. 1 (2012): 62-82; Luin Goldring and Patricia Landolt, "Caught in the Work-Citizenship Matrix: the Lasting Effects of Precarious Legal Status on Work for Toronto Immigrants," Globalizations 8, no. 3 (2011): 325-341.

70 Zia Weisse, “Turkey Plans to Offer Citizenship to Syrian Refugees," accessed July 18, 2016, http://www.telegraph.co.uk/news/2016/07/03/turkey-plans-to-offer-citizenship-to-syrian-refugees/.

71 Fundanur Öztürk, "Suriyeli Mülteciler Vatandaşlık Hakkında Ne Düşünüyor?," accessed December 27, 2016, http://www.bbc.com/turkce/36802877.

72 "Çaresizlikten Buradayız Ülkemize Geri Döneceğiz”, Kelebek, accessed September 30, 2017, http://www.hurriyet.com.tr/caresizlikten-buradayiz-ulkemize-geri-donecegiz-40138220.

73 Sebnem Koser Akcapar, and Dogus Simsek, "The Politics of Syrian Refugees in Turkey: A Question of Inclusion and Exclusion Through Citizenship," Social Inclusion 6, no. 1 (2018): 176-187. 
and making the Aegean Sea a border has instrumental results for both. Turkey has the material interest and may now claim that it is "doing its part" in "burden" sharing. The EU is meanwhile postponing the possibility of solidarity amongst the member-states and resolving the "burden" with a short cut, such as granting material benefits to the third country for being a buffer zone.

\section{Concluding Remarks: Shifting Policy Discourse and Shifting Borders, What Else is There?}

We have examined in this paper how the border first shifted to Aegean Sea once, and then to the Middle East and then back to the Aegean Sea due to Turkey's changing immigration policies and the EU's externalization policies. The changing policy discourse and policy learning regarding human rights show that the direction of Turkish immigration legislation has gone further than previous decrees and temporary measures. However, instrumentalization of migration is still a fact for Turkey and externalization of immigration is still present for the EU. There is also a long way to go when migrants' rights are considered and under which conditions citizenship is granted to refugees. In granting citizenship and reconsidering the readmission deal, maximum transparency is of utmost importance. When the re-establishment of the borders in the Aegean is taken into account, it seems that neither the flows nor the realpolitik of the states will come to a halt.

Changes in policy discourse have not been uni-directional at all, rather policymaking regarding immigration has been a fluctuating process. Moreover, politics of migration within EU institutions and decisions of single EU memberstates have also defined the agenda, perspectives, concepts and decisions. Even when EU-Turkey relations were strained, the enactment of laws and the aim of harmonization are to be retained. All this interaction and the case of refugees who came post-1980s inspired the academic work and NGO-based research in the 1990s where these research articles reached a peak after 2013. After 2015, there has been inflation in the number of works regarding Syrians and their integration. However, these academic works have sufficiently addressed neither the question of borders (with a few exceptions), nor the Aegean Sea from a geographical, critical point of view. Furthermore, the constructive criticism of NGOs that was predominant in the beginning of 2000s seems to be subdued by 2016 .

Another important argument emphasized in this paper was that there has always been movement, mobility and migration within the Aegean. States and borders try to impede upon immigrants' agencies to take control over their lives and give direction to their destinies. Despite this fact, the flows in the Aegean Sea will not end and although the number of lives lost has decreased, there are still crossings and there are still losses. ${ }^{74}$

In this paper we aimed to show, from a historical point of view, that the Aegean Sea and the Mediterranean have been crossing points for those seeking refuge since the late Ottoman times, when homogenization policies gained importance, and during the early Turkish Republican times, when exchange of populations caused great tragedies. Has this phenomenon of nation-states reinstating their borders changed? In response to this question, although the agents are different, the stories are similar.

74 “EU-Turkey Statement One Year On," European Commission, Migration and Home Affairs, accessed July 25, 2018, https://ec.europa.eu/home-affairs/sites/homeaffairs/files/whatwe-do/policies/european-agenda-migration/background-information/eu_turkey_statement_17032017_en.pdf. 
To sum up the interaction of research and policy, the Turkish state's response to immigration policies in diverse areas have been quite influential in terms of what has been produced in academia. Academia in immigration studies in Turkey has taken the world as it is, accepted the laws and implications as they are, in realistic terms just as Turkey and the EU did. Migrant tragedies have also led many policymakers and researchers to lose their imagination and search for pragmatic solutions to structural problems.

The Aegean has been a point of migration throughout history. The TurcoGreek Population Exchange of 1923 was a devastating 20th-century example of this point, through which two states tried to homogenize the population of their nation-states. Turkish policy toward the Second World War's humanitarian crisis in the region fluctuated. Although the reaction of the state to migration was diverse based on different ethnicities, the financial burden regardless of groups was often emphasized. Policymaking in the 1980s was dominated by circular migration and illegal migration; the 1990s revealed works on geographical limitations and refugee rights; the early 2000s witnessed a rise in works regarding securitization, fighting undocumented migration and elaborating on transit migration into the EU. Only after 2006-7, with a slight liberalization of immigration policies, have new horizons arisen in research. A paradigm that dominated each period: "population exchange and homogenization; transit country; counter-trafficking; promoting safe and legal routes for immigration; readmission and negotiation; migration crisis". However, these paradigms do not reflect neither the complete realities nor the agencies of the migrants. They just reflect responses by the sovereign powers, which adopt almost an ahistorical approach to unpreventable border crossings in the Aegean and Mediterranean. Hence, without considering the agency of the migrants and the historical meaning of Aegean Sea for refugees, the border crossings are automatically assigned the adjective "illegal" to this day.

\section{Bibliography}

Archivio Storico del Ministero degli Affari Esteri (ASMAE), Busta Dodecanneso 1, "Trattato di Buon Vicinato fra Turchia e Possedimento," (Good Neighborhood Treaty between Turkey and the Possession), 26 June 1931.

ASMAE, Busta Dodecanneso 13, “Voci Tendenziose sulle Isole dell'Egeo," (Biased Voices on the Aegean Islands), 17 September 1937.

ASMAE, Busta Dodecanneso 16, "Notizie da Rodi," (Information from Rhodes), 13 January 1945, 25 January 1945.

ASMAE, Busta Dodecanneso 16, "Notizie dal Dodecanneso," (Information from the Dodecanese), 25 July 1945.

TC Başbakanlık Cumhuriyet Arşivi, 30..10.0.0/116.84..2, 30 May 1936.

TC Başbakanlık Cumhuriyet Arşivi, 30..10.0.0/124.882..4, 8 March 1943.

TC Başbakanlık Cumhuriyet Arşivi, 30..10.0.0/124.882..12, 2 May 1945.

The National Archives, FO 195/2468, “Telegram from British Consulate General (Symirna) to Sir H. Knatchbull-Hugessen (Angora)," 13 November 1940.

The National Archives, FO 371/29932, "Telegram from Ministry of Economic Warfare to Foreign Office," 11 January 1941.

The National Archives, FO 195/2487, Telegram from Sir M. Peterson to Foreign Office, 5 April 1945.

Alderman, Liz. "Smugglers Prey on Migrants Desperate to Find Back Doors to Europe." Accessed March 11, 2016. https://www.nytimes.com/2016/03/12/world/europe/european-union-migrant-crisis-smuggling.html?mcubz $=0$ \&_r $=0$. 
Akcapar, Sebnem Koser, and Dogus Simsek. "The Politics of Syrian Refugees in Turkey: A Question of Inclusion and Exclusion Through Citizenship." Social Inclusion 6, no. 1 (2018): 176-187.

Aktar, Ayhan. "Homogenising the Nation, Turkifying the Economy." In Crossing the Aegean: An Appraisal of the 1923 Compulsory Population Exchange Between Greece and Turkey, edited by Renée Hirschon, 79-96. New York and Oxford: Berghahn Books, 2003.

Amnesty International UK. "The world's deadliest sea crossing." Accessed September 20, 2017. https://www.amnesty.org.uk/worlds-deadliest-sea-crossing-mediterranean.

Baklacıŏlu, Nurcan Özgur. "“Building “Fortress Turkey': Europeanization of Asylum Policy in Turkey." The Romanian Journal of European Studies 7-8 (2009): 103-119.

Cantat, Celine. "Rethinking Mobilities: Solidarity and Migrant Struggles Beyond Narratives of Crisis." Intersections: East European Journal of Society and Politics 2, no. 4 (2016): 11-32.

Collyer, Michael. "Stranded Migrants and the Fragmented Journey." Journal of Refugee Studies 23, no. 3 (2010): 273-293.

Danacıoğlu-Tamur, Esra. “Ege'de Büyük Kaçış: II. Dünya Savaşı'nda Adalardan Türkiye'ye Mülteci Akını." Toplumsal Tarih 25, no. 146 (Şubat 2006): 50-55.

Divani, Lena and Photini Konstantopoulou, eds. The Dodecanese: The Long Road to Union with Greece: Diplomatic Documents from the Historical Archives of the Ministry of Foreign Affairs. Athens: Kastaniotis Editions, 1997.

Dündar, Fuat. İttihat ve Terakki'nin Müslümanları İskân Politikası (1913-1918). İstanbul: İletişim Yayınları, 2002.

Düvell, Franck. "Transit Migration: A Blurred and Politicised Concept." Population, Space and Place 18, no. 4 (2012): 415-427.

Erdoğan, M. Murat. Türkiye'deki Suriyeliler: Toplumsal Kabul ve Uyum. İstanbul: İstanbul Bilgi Üniversitesi Yayınları, 2015.

European Commission, Migration and Home Affairs. "EU-Turkey Statement One Year On." Accessed July 25, 2018. https://ec.europa.eu/home-affairs/sites/homeaffairs/ files/what-we-do/policies/european-agenda-migration/background-information/ eu_turkey_statement_17032017_en.pdf.

European Commission, Migration and Home Affairs. "Temporary protection." Accessed October 14, 2017. https://ec.europa.eu/home-affairs/what-we-do/policies/asylum/ temporary-protection_en.

European Commission, European Civil Protection and Humanitarian Aid Operations. "Syria." Accessed October 14, 2017. http://ec.europa.eu/echo/files/aid/countries/factsheets/turkey_syrian_crisis_en.pdf.

Featherstone, Kevin et al. The Last Ottomans: The Muslim Minority of Greece, 1940-1949. New York: Palgrave Macmillan, 2011.

Goldring, Luin and Patricia Landolt. "Caught in the Work-Citizenship Matrix: the Lasting Effects of Precarious Legal Status on Work for Toronto Immigrants." Globalizations 8, no. 3 (2011): 325-341.

Hirschon, Renée. "The Consequences of the Lausanne Convention: An Overview." In Crossing the Aegean: An Appraisal of the 1923 Compulsory Population Exchange Between Greece and Turkey, edited by Renée Hirschon, 13-20. New York and Oxford: Berghahn, 2003.

Hirschon, Renée, ed. Crossing the Aegean: An Appraisal of the 1923 Compulsory Population Exchange Between Greece and Turkey. New York and Oxford: Berghahn, 2003.

Hirschon, Renée. "Unmixing Peoples in the Aegean Region." In Crossing the Aegean: An Appraisal of the 1923 Compulsory Population Exchange Between Greece and Turkey, edited by Renée Hirschon, 3-12. New York and Oxford: Berghahn, 2003.

Hoffmann, Sophia and Sahizer Samuk. "Turkish Immigration Politics and the Syrian Refugee Crisis." Working Paper Research Division Global Issues, no. 01, March 2016. 
İçduygu Ahmet. "EU-ization Matters: Changes in Immigration and Asylum Practices in Turkey." In The Europeanization of National Policies and Politics of Immigration: Migration, Minorities and Citizenship, edited by Thomas Faist and Andreas Ette, 201-222. London: Palgrave Macmillan, 2007.

İçduygu, Ahmet. The Irregular Migration Corridor Between the EU and Turkey: Is It Possible to Block It with a Readmission Agreement? Research Report Case Study EU-US Immigration Systems 2011/14, Robert Schuman Centre for Advanced Studies, San Domenico di Fiesole (FI): European University Institute, 2011.

İçduygu, Ahmet, and E. Fuat Keyman. "Globalization, Security, and Migration: The Case of Turkey." Global Governance 6 (2000): 383-398.

İçduygu, Ahmet, and Kemal Kirişci. "Introduction: Turkey's International Migration in Transition." In Land of Diverse Migrations: Challenges of Emigration and Immigration in Turkey, edited by Ahmet İçduygu and Kemal Kirişci, 1-35. İstanbul: İstanbul Bilgi University Press, 2009.

İçduygu, Ahmet, and Şule Toktaş. "How Do Smuggling and Trafficking Operate via Irregular Border Crossings in the Middle East? Evidence from Fieldwork in Turkey." International Migration 40, no. 6 (2002): 25-54.

İçduygu, Ahmet, Şule Toktas, and B. Ali Soner. "The Politics of Population in a Nationbuilding Process: Emigration of Non-Muslims from Turkey." Ethnic and Racial Studies 31, no. 2 (2008): 358-389.

International Organization for Migration. "Missing Families Project." Accessed October 14, 2017. https://missingmigrants.iom.int/region/mediterranean.

Karakuş, Önder. "A Quantitative Analysis of the Growing Business of Organized Crime: Structural Predictors of Cross-national Distribution of Human Trafficking Markets and Trafficking in Women in Turkey." PhD diss., Michigan State University, 2008.

Karpat, Kemal. Ottoman Population, 1830-1914: Demographic and Social Characteristics. Madison, Wisconsin: University of Wisconsin Press, 1985.

Kaşka, Selmin. "The New International Migration and Migrant Women in Turkey: The Case of Moldovan Domestic Workers." MiReKoc Research Project 25, 2006.

Kelebek. "Çaresizlikten Buradayız Ülkemize Geri Döneceğiz." Accessed September 30, 2017. http://www.hurriyet.com.tr/caresizlikten-buradayiz-ulkemize-geri-donecegiz-40138220.

Keser, Ulvi. Yunanistan'ın Büyük Açlık Dönemi ve Türkiye. İstanbul: IQ Kültür Sanat Yayınları, 2008.

Kingsley, Patrick. "Fewer than 0.1\% of Syrians in Turkey in Line for Work Permits." Accessed April 11, 2016. https://www.theguardian.com/world/2016/apr/11/fewer-than01-of-syrians-in-turkey-in-line-for-work-permits.

Kirişci, Kemal. “Turkey: A Country of Transition from Emigration to Immigration.” Mediterranean Politics 12, no. 1 (2007): 91-97.

Kirişci, Kemal. Managing Irregular Migration in Turkey: A Political-bureaucratic Perspective. CARIM-AS 2008/61. Robert Schuman Centre for Advance Studies, San Domenico di Fiesole (FI): European University Institute, 2008.

Kofman, Eleonore and Rosemary Sales. "Towards Fortress Europe?." Women's Studies International Forum 15, no. 1 (Pergamon, 1992): 29-39.

MigPolGroup. "Migration \& Mobility." Accessed September 22, 2017. http://www. migpolgroup.com/migration-mobility/.

Orient Net. “UNHCR Praises Turkey's Work Permits for Syrian Refugees." Accessed September 30，2017. http://orient-news.net/en/news_show/100179/0/UNHCR-praisesTurkeys-work-permits-for-Syrian-refugees.

Özçürümez, Saime and Nazlı Şenses. "Europeanization and Turkey: Studying Irregular Migration Policy." Journal of Balkan and Near Eastern Studies 13, no. 2 (2011): 233-248.

Öztürk, Fundanur. "Suriyeli Mülteciler Vatandaşlık Hakkında Ne Düşünüyor?." Accessed December 27, 2016. http://www.bbc.com/turkce/36802877. 
Preibisch, Kerry. "Migrant Workers and Changing Work-place Regimes in Contemporary Agricultural Production in Canada." International Journal of Sociology of Agriculture E Food 19, no. 1 (2012): 62-82.

Republic of Turkey, Ministry of Interior Directorate General of Migration Management. "Statistics." Accessed December 30, 2016. http://www.goc.gov.tr/icerik3/statistics_1064_4773_10166.

Rhodes Jewish Museum. "Holocaust." Accessed 13 January, 2013. http://www.rhodesjewishmuseum.org/history/holocaust.

Squires, Nick. "A Year on from EU-Turkey Deal, Refugees and Migrants in Limbo Commit Suicide and Suffer from Trauma." Accessed March 14, 2017. https://www.telegraph.co.uk/news/2017/03/14/year-eu-turkey-deal-refugees-migrants-limbo-commit-suicide-suffer/.

Toğral Koca, Burcu. “Deconstructing Turkey's ‘Open Door’ Policy towards Refugees from Syria." Migration Letters 12, no. 3 (2015): 209-225.

United Nations High Commissioner for Refugees (UNHCR). "Mediterranean Takes Record as Most Deadly Stretch of Water for Refugees and Migrants in 2011." Accessed October 14, 2017. http://www.unhcr.org/news/briefing/2012/1/4f27e01f9/ mediterranean-takes-record-deadly-stretch-water-refugees-migrants-2011.html.

Vertovec, Steven. "Super-diversity and Its Implications." Ethnic and Racial Studies 30, no. 6 (2007): 1024-1054.

Weisse, Zia. "Turkey Plans to Offer Citizenship to Syrian Refugees." Accessed July 18, 2016. http://www.telegraph.co.uk/news/2016/07/03/turkey-plans-to-offer-citizenship-to-syrian-refugees/.

Ylldirım, Onur. Diplomacy and Displacement: Reconsidering the Turco-Greek Exchange of Populations, 1922-1934. New York: Routledge, 2006.

Yükseker, Deniz. "Shuttling Goods, Weaving Consumer Tastes: Informal Trade Between Turkey and Russia." International Journal of Urban and Regional Research 31, no. 1 (2007): 60-72. 